\title{
Karakteristik Morfologi dan Klasifikasi Tanah Andisol di Lahan Kering Kabupaten Aceh Besar
}

\author{
(Characteristics Morphology and Soil Classification of Andisol at Dry Land \\ in Aceh Besar District)
}

\author{
Ferdeanty ${ }^{1}$, Sufardi ${ }^{1}$, Teti Arabia ${ }^{{ }^{*}}$ \\ ${ }^{1}$ Program Studi Ilmu Tanah, Fakultas Pertanian, Universitas Syiah Kuala \\ Corresponding author: tetiarabia@unsyiah.ac.id
}

\begin{abstract}
Abstrak. Andisol di BBH Gampong Aceh/Lembah Seulawah berasal dari bahan induk berupa batuan gunung api andesit - dasit, berbatu apung, tufa dan aglomerat pada zaman kuarter kala Plistosen - Holosen $(0,6$ juta tahun yang lalu). Berada pada ketinggian $453 \mathrm{~m}$ dpl., dengan bentuk relief miring. Tipe iklim wilayah Aceh Besar tergolong tipe iklim $\mathrm{C}$, rejim kelembaban tergolong udik, dan rejim suhu tanah isohipertermik. Dicirikan oleh: struktur tanah remah; konsistensi tanah basah agak lekat; terasa licin (smeary); sifat tanah andik pada horizon Bw: C-organik < 25\% (1,42\%); bobot isi tanah < $0,90 \mathrm{~g} \mathrm{~cm}^{-3}\left(0,73 \mathrm{~g} \mathrm{~cm}^{-3}\right)$; P-retensi $\geq 85 \%(99,90 \%)$; dan kadar Alo + 1/2 Feo $\geq 2 \%$ (5,51\%); epipedon umbrik: tebal horizon $\mathrm{AB} \geq 18 \mathrm{~cm}(18 \mathrm{~cm})$; value lembab < 3 (3); Corganik $\geq 0,6 \%(3,95 \%)$; dan $\mathrm{KB} \mathrm{pH7}<50 \%(10,62 \%)$. Horizon penciri bawah kambik: tekstur pasir sangat halus atau lebih halus (lempung berdebu); atau warna tanah lebih merah dari horizon diatasnya atau dibawahnya (sama-sama 7,5YR 3/4); atau struktur telah terbentuk (gumpal bersudut). Subordo dikategorikan Udand, great group Hydrudand, subgrup Eutric Hydrudand, dan tingkat famili Eutric Hydrudand, medial, campuran, isohipertermik.
\end{abstract}

Kata Kunci: Andisol, karakteristik morfologi, klasifikasi tanah.

\begin{abstract}
Andisols in BBH, Gampong Aceh/Lembah Seulawah are derived from the parent material in the form of andesite - dacite volcanic rocks, rocky floats, tuffs and agglomerates in the quarter-time period of the Plistocene-Holocene (0.6 million years ago). Located at an altitude of $453 \mathrm{~m}$ above sea level, with oblique relief. The climate type of the Greater Aceh region is classified as climate type C, humidity regimes are classified as hick, and isohyperthermic soil temperature regimes. Characterized by: crumb soil structure; the consistency of wet soils rather closely; feels slippery (smeary); andik soil characteristics on the Bw horizon: C-organic < $25 \%$ (1.42\%); soil weight weight $<0.90 \mathrm{~g} \mathrm{~cm}^{-3}\left(0.73 \mathrm{~g} \mathrm{~cm}^{-3}\right)$; P-retention $\geq 85 \%$ (99.90\%); and Alo $+1 / 2$ Feo $\geq 2 \%$ (5.51\%); Umbrik epipedon: horizon thickness $\mathrm{AB} \geq 18 \mathrm{~cm}(18 \mathrm{~cm})$; moist value $<3$ (3); C-organic $\geq 0.6 \%$ (3.95\%); and $\mathrm{KB} \mathrm{pH} 7<50 \%(10.62 \%)$. Horizon characterizes the bottom of the cambic: the texture of the sand is very fine or finer (dusty clay); or the color of the soil is redder than the horizon above or below (both 7.5YR $3 / 4$ ); or structures have formed (angular lumps. The suborder is categorized as Udand, the great Hydrudand group, the Eutric Hydrudand subgroup, and the level of the Eutric Hydrudand family, medial, mixed, isohyperthermic.
\end{abstract}

Keywords: Andisol, characteristics morphology, soil classification.

\section{PENDAHULUAN}

Berbagai macam sifat tanah secara alamiah terjadi dari faktor dan proses pembentukannya, dimulai dari bahan induk yang berkembang menjadi tanah di berbagai kondisi lahan (Adiwiganda, 1998). Berdasarkan pengamatan morfologi tanah di lapangan dapat dijumpai bentuk fisik tanah yang sama atau berbda antara satu tanah dengan tanh lainnya, kondisi fisik tanah yang berbeda diberikan sebuah nama untuk mencerminkan sifat dan ciri dominan yang dimilikinya (Fiantis, 2012). 
Karakteristik morfologi tanah yang diperhatikan, antara lain batas horison, warna, tekstur, struktur, dan konsistensi tanah (Purnomo, 2003). Klasifikasi tanah erat kaitannya dengan proses-proses pembentukan tanah dan faktor pembentuknya (Arabia et al., 2012). Sistem Taksonomi tanah yang digunakan untuk klasifikasi meliputi dua kategori yaitu kategori tertinggi dan terendah. Urutan kategori ini meliputi: ordo, subordo, great group, subgrup, dan famili. Untuk setiap kategori mempunyai kriteria pembeda yang harus dipahami dan dilalui secara sistematis hingga akhirnya tanah yang di survei dapat diklasifikasikan sesuai dengan keadaan morfologi tanah di lapangan dan dari hasil analisis tanah di laboratorium (Fiantis, 2012).

Andisol merupakan tanah yang berasal dari bahan induk tuf vulkanik dan abu vulkanik tergolong relatif masih muda (Handayanto, 1987). Karakteristik tanah dicirikan berwarna hitam, porous, kandungan bahan organik dan lempung berbentuk amorf, yaitu alofan kemudian sedikit silika, alumina atau hidroksida-besi (Darmawijaya, 1990). Tanah yang digolongkan ordo Andisol adalah tanah yang memiliki sifat andik pada seluruh sub horisonnya, dapat tertimbun maupun yang tidak tertimbun, ketebalan secara kumulatif $35 \mathrm{~cm}$ atau lebih pada kedalaman $60 \mathrm{~cm}$ dari permukaan tanah mineral atau di atas lapisan organik yang memiliki sifat andik dengan ketebalan dangkal. Di bawah lapisan dengan sifat tanah andik tersebut, tanah dapat memiliki sembarang horison penciri. Syarat tersebutlah minimum untuk Andisol. Apabila syarat ini terpenuhi maka tanah tersebut digolongkan Andisol, apapun sifat tanah yang dibawahnya (Soil Survey Staff, 1990). Karakteristik morfologi dan klasifikasi tanah dapat mendukung pengetahuan tentang kendala dan potensi pemanfaatan Andisol dalam pengembangan pertanian di daerah lahan kering Kabupaten Aceh Besar.

\section{METODE PENELITIAN}

Metode yang digunakan dalam penelitian ini adalah metode survai deskriptif kuantiattif yang didasarkan pada pengamatan ciri-ciri tanah di lapangan dan analisis tanah di laboratorium. Pengamatan morfologi dan klasifikasi tanah Andisol dilakukan di $\mathrm{BBH}$ Gampong Aceh/Lembah Seulawah (05²7’03,2’LU; 9543’45,2”BT) Kabupaten Aceh Besar. Analisis sifat fisika dan kimia tanah dilakukan di Laboratorium Penelitian Tanah dan Tanaman Fakultas Pertanian Universitas Syiah Kuala, dan Laboratorium Fisika Material Fakultas MIPA Universitas Syiah Kuala untuk analisis kandungan mineral tanah.

Penelitian dilakukan pada bulan Juli sampai Oktober 2018. Alat yang digunakan untuk penggalian dan deskripsi profil tanah di lapangan adalah bor tanah, cangkul, sekop, pisau, plastik berukuran $2 \mathrm{~kg}$, kertas label, $\mathrm{pH}$ tancap, meteran, buku penuntun Dasar-dasar Ilmu Tanah, buku Munsell Soil Colour Chart, buku Keys to Soil Taxonomy, global positioning system (GPS), Abney level, form pengisian data, Ring sample, alat tulis dan larutan kimia $\mathrm{H}_{2} \mathrm{O}_{2} 30 \%$ dan $\mathrm{HCl} 10 \%$. Peralatan yang digunakan untuk analisis di laboratorium adalah botol film, labu ukur, shaker, kertas saring, timbangan, ayakan, alat tumbuk, pipet ukur, oven, sentrifus, flame fotometer, spektrofotometer dan atomic absorpsion spectrophotometry (AAS) model 7000S. Bahan kimia yang digunakan meliputi alkohol, akuades, larutan kalium dikromat $\left(\mathrm{K}_{2} \mathrm{Cr}_{2} \mathrm{O}_{7}\right)$, asam sulfur pekat $\left(\mathrm{H}_{2} \mathrm{SO}_{4}\right)$, amonium asetat $\left(\mathrm{NH}_{4} \mathrm{OAc}\right) \mathrm{pH} 7, \mathrm{NaCl} 10 \%$, dan pengekstrak $\mathrm{KCl}$ dan larutan amonium oksalat.

Pembuatan profil tanah diawali dengan melihat peta dasar/peta kerja untuk melihat kecocokan jenis tanahnya, kemudian melakukan penjelajahan lokasi dengan beberapa kali 
pemboran, setelah dianggap mewakili maka dilakukanlah pembuatan profil tanah pewakil. Pembuatan profil tanah dilakukan dengan penggalian profil tanah dengan panjang $\mathrm{x}$ lebar $\mathrm{x}$ dalam $(150 \mathrm{~cm} \times 100 \mathrm{~cm}$ x $150 \mathrm{~cm})$ hingga sampai terdapat lapisan bahan induk.

Pengisian data profil tanah meliputi pengamatan terhadap keadaan lingkungan lahan seperti cuaca, tinggi tempat, kelerengan, vegetasi, dan penggunaan lahan serta pengamatan sifat-sifat morfologi tanah seperti susunan horizon, warna, tekstur, struktur, konsistensi/ plastisitas, karatan, perakaran, dan $\mathrm{pH}$ tanah di lapangan. Batas lapisan tiap horizon ditandai atau diberi garis, masing-masing horizon diamati dari atas sampai ke bahan induknya. Apabila telah diperoleh keterangan dari setiap horizon, maka simbol horizonnya dapat ditentukan. Untuk keperluan analisis di laboratorium, sampel-sampel tanah diambil pada setiap lapisan horizon.

\section{Analisis Tanah di Laboratroium}

Sampel tanah yang telah diambil dari lapangan sebelum dianalisis dikering-anginkan terlebih dahulu selama 1 minggu, setelah itu ditumbuk dan diayak menggunakan ayakan 2,0 untuk analisis tekstur tanah dan menggunakan ayakan $0,5 \mathrm{~mm}$ untuk analisis sifat-sifat kimia tanah seperti $\mathrm{pH}$, C-organik, kation basa dapat ditukar (Ca-dd, Mg-dd, K-dd, dan Na-dd), kapasitas tukar kation (KTK), kejenuhan basa (KB), serta kemasaman tanah dapat ditukar (Al-dd dan H-dd). Metode dan prosedur analisis tanah berpedoman pada prosedur yang dikeluarkan oleh Pusat Penelitian Tanah Bogor (2009).

\section{Analisis Data}

Hasil data yang diperoleh dari pengamatan lapangan dan analisis tanah di laboratorium digunakan untuk mengidentifikasi karakteristik morfologi tanah, yaitu berupa horizon genetik (contoh: horison $\mathrm{O}, \mathrm{A}, \mathrm{B}$, dan $\mathrm{C}$ ); horizon penciri atas/epipedon (contoh: molik, umbrik, okrik, dan melanik); horizon penciri bawah (contoh: kambik dan oksik); serta pemberian simbol-simbol horizon (contoh: Bw dan Bo) di lapangan dan beserta klasifikasi jenis tanah dilakukan berdasarkan buku Keys to Soil Taxonomy (Soil Survey Staff, 2014).

\section{HASIL DAN PEMBAHASAN}

\section{A. Karakteristik Umum Lokasi}

Berdasarkan Pusat Penelitian dan Pengembangan Geologi (1981), Andisol di BBH Gampong Aceh/Lembah seulawah berasal dari batuan gunung api andesit hingga dasit, berbatu apung, tufa dan aglomerat. Andisol terbentuk pada zaman kuarter kala Plistosen sampai Holosen. Menurut Arabia et al. (2015) zaman kuarter merupakan zaman yang dimulai sejak sekitar 0,6 juta tahun yang lalu sampai sekarang. Terdiri atas dua kala, yaitu Kala Plistosen (Diluvium) dan Kala Holosen (Alluvium). Kala Plistosen menunjukkan sebagian besar jenis kehidupannya banyak kesamaan dengan kehidupan sekarang dan dapat ditemukan dimana-mana, sedangkan kala Halosen menunjukkan kala manusia yang merajai dunia dan tidak ada satu tempat pun yang belum dijamah oleh manusia.

Topografi di lokasi penelitian tergolong miring, berada pada ketinggian tempat $453 \mathrm{~m}$ dpl., dan tergolong memiliki bentuk lereng yang cembung. Berdasarkan hasil pengamatan di lapangan, profil tanah Andisol memiliki kemiringan lereng 20 - 30\% dengan kondisi tanah 
agak curam atau berbukit, run-off cepat sampai sangat cepat dan terkena erosi. Kabupaten Aceh Besar berada di wilayah tropis, musim kemarau dan musim penghujan, sehingga tipe iklim di Kabupaten Aceh Besar menurut Schmidt dan Ferguson digolongkan kedalam tipe iklim C. Vegetasi yang terdapat disekitar profil Andisol adalah jenis rumput-rumputan seperti rumput jarum, rumput setaria, ilalang dan orok-orok, tidak jauh dari lokasi penelitian daerah tersebut sudah digunakan sebagai lahan budidaya masyarakat, karena termasuk bagian wilayah pertanian lahan kering.

\section{B. Karakteristik Morfologi Tanah}

Karakteristik morfologi tanah di lokasi penelitian dapat dilihat pada Tabel 1. Tabel 1. Data Karakteristik Morfologi Tanah

\begin{tabular}{lcccccccc}
\hline $\begin{array}{l}\text { Horizon/ } \\
\text { Kedalaman } \\
(\mathrm{cm})\end{array}$ & $\begin{array}{c}\text { Batas } \\
\text { Horizon }\end{array}$ & $\begin{array}{c}\text { Batas } \\
\text { Topografi }\end{array}$ & $\begin{array}{c}\text { Marna } \\
\text { Tatriks } \\
\text { Tanah }\end{array}$ & $\begin{array}{c}\text { Tekstur } \\
\text { tanah }\end{array}$ & $\begin{array}{c}\text { Struktur } \\
\text { Tanah }\end{array}$ & Basah & Lembab & Ponsistensi \\
\hline Ap/0 - 20 & $\mathrm{~b}$ & $\mathrm{Bg}$ & $10 \mathrm{YR}^{4} / 4$ & $\mathrm{H}$ & $\mathrm{r}$, sh & $\mathrm{Gb}$ & $\mathrm{alk}$ & $\mathrm{Pl}$ \\
$\mathrm{AB} / 20-38$ & $\mathrm{~b}$ & $\mathrm{Bg}$ & $7,5 \mathrm{YR}^{3 / 4}$ & $\mathrm{~J}$ & $\mathrm{gs}, \mathrm{sd}$ & $\mathrm{Gb}$ & alk & $\mathrm{Pl}$ \\
$\mathrm{Bw} / 38-60$ & $\mathrm{~b}$ & $\mathrm{Bg}$ & $7,5 \mathrm{YR}^{3} / 4$ & $\mathrm{~J}$ & $\mathrm{gs}, \mathrm{bs} *$ & $\mathrm{~Gb}$ & tlk & $\mathrm{Pl}$ \\
$\mathrm{BC} />60$ & $\mathrm{~b}$ & $\mathrm{Bg}$ & $7,5 \mathrm{YR}^{4} / 4$ & $\mathrm{H}$ & $\mathrm{gs}, \mathrm{bs} *$ & $\mathrm{~Gb}$ & tlk & $\mathrm{Pl}$ \\
\hline
\end{tabular}

Sumber: Hasil Survey Lapangan (2018)

Keterangan:10YR 4/4= Brown; 7,5YR $3 / 4=$ Dark Brown; b (baur); bg (bergelombang); P (plastisitas); pl (plastis); H (lempung berdebu); J (debu); r (remah); sd (dedang); bs* (besar); alk (agak lekat); lk (lekat); tlk (tidak lekat).

\section{Susunan dan Batas Horizon}

Hasil pengamatan profil tanah Andisol di BBH Gampong Aceh/Lembah Seulawah berdasarkan Tabel 1, memperlihatkan susunan horizon tanah terdiri atas lapisan olah Ap pada kedalaman tanah $0-20 \mathrm{~cm}$. Beralih ke horizon AB pada kedalaman $20-30 \mathrm{~cm}$, yaitu horizon peralihan A ke B tetapi masih menyerupai horizon A. Pada kedalaman $30-60 \mathrm{~cm}$ telah dijumpai horizon penciri $\mathrm{Bw}$, yaitu horizon $\mathrm{B}$ yang baru ada perkembangan warna dan struktur atau kedua-duanya, dengan adanya sedikit atau tanpa akumulasi iluvial bahan tanah tertentu. Selanjutnya, beralih ke horizon BC pada kedalaman $\pm 60 \mathrm{~cm}$, yaitu horizon peralihan B ke C tetapi lebih menyerupai horizon B. Batas horizon pada setiap lapisan tanah baur dengan tebal peralihan $\pm 12,5 \mathrm{~cm}$ dan batas topografi bergelombang. Batas horizon pada profil tanah tergantung pada tingkat pelapukan bahan induk dan bahan organik tanah. Hal ini dapat diamati pada horizon Ap yang memiliki bahan organik lebih banyak dibandingkan horizon lainnya yang memiliki bahan organik lebih sedikit.

\section{Warna Tanah}

Warna tanah Andisol berdasarkan Tabel 1 pada horizon Ap yaitu 10YR 4/4 (cokelat), sedangkan warna tanah horizon $\mathrm{AB}, \mathrm{Bw}$, dan $\mathrm{BC}$ berkisar 7,5YR 3/4 (cokelat kehitaman). Umumnya tanah Andisol berwarna hitam sampai cokelat tua. Warna hitam menandakan adanya akumulasi bahan organik yang merupakan asal asam humat yang terekstrak serta pengaruh dari bahan abu vulkan, hasil kegiatan gunung berapi. Hasil penelitian Arabia et al. (2015b) di University Farm Bener Meriah juga memperlihatkan warna tanah pada pedon 1 berkisar dari hitam $(7,5 \mathrm{YR} 2.5 / 1)$ sampai cokelat tua $(7,5 \mathrm{YR} 5 / 8)$, pada pedon 2 memiliki warna hitam keabu-abuan (10YR $4 / 6)$, dan pada pedon 3 memiliki kisaran warna dari hitam $\left(5 \mathrm{YR}^{2,5} / 1\right.$ ) sampai cokelat $\left(10 \mathrm{YR}^{5 / 3}\right)$. Warna gelap pada horizon permukaan disebabkan oleh kandungan C-organik yang tinggi dan menurun semakin kebawah. Jika pada horizon bawah terdapat warna tanah lebih gelap/hitam dari horizon di atasnya menunjukkan horizon tersebut merupakan horizon penimbunan hasil erupsi vulkanik yang terjadi berulang-ulang. 


\section{Tesktur dan Struktur Tanah}

Umumnya jenis tanah Andisol ketika dipirid terasa licin (smeary) karena mengandung fraksi debu yang lebih dominan. Berdasarkan hasil pengamatan dilapangan, tekstur tanah Andisol pada tiap horizon (Ap - AB - Bw dan BC) digolongkan memiliki tekstur tanah lempung berdebu dan smeary. Hal ini disebabkan karena pada saat menentukan tekstur tanah dilapangan dengan cara memijit tanah dengan jari-jari terasa halus, agak licin, mudah membentuk bola, serta sangat lekat dan mudah digulung.

Hasil analisis fraksi pasir Andisol di laboratorium, diperoleh persentase fraksi pasir di lapisan olah (Ap) adalah 14\%, debu 79\% dan liat 7\% dengan ketebalan tanah $20 \mathrm{~cm}$. Horizon $\mathrm{AB}$ dengan ketebalan tanah $18 \mathrm{~cm}$ memiliki persentase fraksi pasir $13 \%$, debu $81 \%$, dan liat $6 \%$. Pada horizon $\mathrm{Bw}$ yang mencirikan sifat tanah andik dengan ketebalan tanah $22 \mathrm{~cm}$ memiliki fraksi pasir $13 \%$, debu $80 \%$, dan liat 7\%. Horizon terakhir (BC) mempunyai fraksi pasir $17 \%$, debu $77 \%$, dan liat $6 \%$ dengan ketebalan tanah $\pm 22 \mathrm{~cm}$. Dari hasil analisis tersebut dapat dikatakan bahwa tanah Andisol di BBH Gampong Aceh/Lembah Seulawah tersebut didominasi oleh kandungan debu yang tinggi pada tiap horizonnya. Hal ini disebabkan karena tanah tersebut mengandung bahan volkanik, seperti abu volkan dan lava yang memiliki fraksi koloid didominasi oleh mineral short-range order, seperti alofan, imogolit, dan ferihidrit.

Struktur tanah pada lapisan olah tanah (Ap) tergolong remah, karena gumpalan tanah yang diambil sangat porous dan agregat tidak terikat sesamanya. Horizon $\mathrm{AB}, \mathrm{Bw}$ dan $\mathrm{BC}$ memiliki struktur gumpal bersudut, dimana sisi agregat tanah membentuk sudut yang tajam. Tingkat perkembangan atau kematangan struktur tanah untuk tiap horizonnya dicirikan sedang, di karenakan ketika diambil dari profil untuk diperiksa butir struktur tanah agak kuat dan tidak mudah hancur. Berdasarkan penelitian Arabia et al. (2015a), klasifikasi Andosol di University Farm Bener Meriah memiliki struktur tanah yang remah pada semua horizonhorizon tanah (P1, P2, dan P3). Hasil pengamatan tekstur dan struktur Andisol dapat dilihat pada Tabel 1.

\section{Konsistensi Tanah}

Konsistensi tanah Andisol di lapangan berdasarkan Tabel 1, pada horizon Ap dan AB dalam kondisi basah digolongkan agak lekat dan plastis dimana tanah tersebut dapat dibentuk seperti gulungan dan adanya sedikit tekanan yang diperlukan untuk merusak gulungan tersebut. Konsistensi tanah dalam keadaan lembab perlu adanya sedikit tekanan untuk menghancurkan tanah tersebut, sehingga di golongkan gembur. Pada horizon $\mathrm{Bw}$ dan $\mathrm{BC}$ konsistensi tanah dalam kondisi basah tidak lekat tetapi plastis, dan pada kondisi lembab digolongkan memiliki konsistensi yang gembur. Hasil penelitian Arabia et al. (2015b) pada tanah Typic Hapludand di daerah University Farm Bener Meriah memiliki konsistensi tanah dalam kondisi lembab di lapisan olah (Ap) adalah gembur dan dalam kondisi basah yaitu agak lekat sampai tidak lekat. Pada lapisan bawah, konsistensi tanah dalam kondisi lembab adalah sangat gembur sampai gembur, dan dalam kondisi basah tergolong agak lekat sampai tidak lekat.

\section{Sifat Fisika dan Kimia Tanah}

Sifat Fisika dan Kimia tanah Andisol dapat dilihat pada Tabel 2. 
Tabel 2. Data Sifat Fisika dan Kimia tanah Andisol

\begin{tabular}{|c|c|c|c|c|c|c|c|c|c|c|c|c|c|}
\hline \multirow{3}{*}{$\begin{array}{l}\text { Horizon } \\
(\mathrm{cm})\end{array}$} & \multirow{3}{*}{$\begin{array}{c}\mathrm{pH} \\
\mathrm{NaF}\end{array}$} & \multirow{2}{*}{$\begin{array}{c}\text { Bulk } \\
\text { density }\end{array}$} & \multirow{2}{*}{$\begin{array}{c}\text { C- } \\
\text { Organik }\end{array}$} & \multicolumn{4}{|c|}{ Kation basa $a_{d d}$} & \multicolumn{2}{|c|}{ Asam $_{\text {dd }}$} & \multirow{2}{*}{ KTK } & \multirow{2}{*}{$\begin{array}{c}\mathrm{P}- \\
\text { retensi }\end{array}$} & \multirow[t]{2}{*}{ KB } & \multirow{2}{*}{$\begin{array}{l}1 / 2 \mathrm{Feo} \\
+\mathrm{Alo}\end{array}$} \\
\hline & & & & $\mathrm{K}$ & $\mathrm{Na}$ & $\mathrm{Ca}$ & $\mathrm{Mg}$ & $\mathrm{H}$ & $\mathrm{Al}$ & & & & \\
\hline & & $-\mathrm{g} \mathrm{cm}^{-3}-$ & $-\%-$ & \multicolumn{7}{|c|}{---------------------cmol kg ${ }^{-1}$------------------- } & \multicolumn{3}{|c|}{----------------\%"----------- } \\
\hline $0-20$ & נת & - & 4,44 & 0,24 & 0,18 & 3,08 & 0,34 & 0,80 & 1,00 & 31,60 & - & 12,15 & 3,35 \\
\hline $\mathrm{AB} / 20-38$ & 10,88 & 0,72 & 3,95 & 0,14 & 0,19 & 2,42 & 0,35 & 0,48 & 0,72 & 29 , & 99,80 & 10,62 & 5,52 \\
\hline $\mathrm{Bw} / 38-60$ & 10,78 & 0,73 & 1,42 & 0,38 & 0,21 & 3,23 & 0,36 & tu & 0,32 & 25 & 99,90 & 16,59 & 5,51 \\
\hline $\mathrm{BC} />60$ & 10,55 & - & 0,98 & 0,19 & 0,22 & 4,14 & 0,36 & $\mathrm{tu}$ & 0,24 & 26,40 & - & 18,60 & 4,90 \\
\hline
\end{tabular}

Sumber: Hasil Analisis Laboratorium Fisika Tanah dan Penelitian Tanah dan Tanaman Fakultas Pertanian Universitas Syiah Kuala (2018)

\section{Reaksi Tanah (pH)}

Berdasarkan Tabel 2 hasil pengukuran reaksi tanah $\mathrm{H}_{2} \mathrm{O}$ Andisol pada setiap horizon dikategorikan agak masam berkisar antara 5,30 - 6,06, sedangkan $\mathrm{pH} \mathrm{KCl}$ di lapangan untuk setiap horizonnya berkisar dari 4,25 - 4,64. Nilai $\mathrm{pH} \mathrm{H}_{2} \mathrm{O}$ tanah Andisol lebih tinggi dibandingkan dengan $\mathrm{pH} \mathrm{KCl}$ yang diamati dilapangan, hal ini menunjukkan bahwa tanah tersebut berada dalam kondisi subur. Pengukuran $\mathrm{pH}$ sodium fluoride ( $\mathrm{pH} \mathrm{NaF}$ ) Andisol pada horizon Ap memiliki nilai 10,89, horizon AB bernilai 10,88, horizon Bw bernilai 10,78, dan horizon BC bernilai 10,55.

\section{Bobot Isi (Bulk Density)}

Analisis bulk density Andisol dilakukan pada horizon AB dengan kedalaman tanah 20 $38 \mathrm{~cm}$ dan di horizon Bw dengan kedalaman tanah $38-60 \mathrm{~cm}$. Hasil bobot isi tanah Andisol dapat digunakan sebagai data pendukung yang menunjang kemungkinan dalam profil tersebut memiliki nilai bobot isi tanah yang rendah. Hasil analisis di laboratorium menunjukkan bahwa bobot isi tanah Andisol digolongkan memiliki kriteria rendah/ringan, dengan hasil bobot isi pada horizon $A B$ yaitu $0,72 \mathrm{~g} \mathrm{~cm}^{-3}$ dan pada horizon $\mathrm{Bw}$ yaitu $0,73 \mathrm{~g} \mathrm{~cm}^{-3}$. Hal tersebut sesuai dengan struktur tanah di lapangan, memiliki struktur tanah yang remah atau pori-pori tanah yang dominan terkandung di dalamnya adalah pori makro. Berdasarkan buku Kunci Taksonomi Tanah (2014), karakteristik yang diperlukan untuk bobot isi tanah Andisol adalah $0,90 \mathrm{~g} \mathrm{~cm}^{-3}$ atau kurang, dengan kata lain hasil bobot isi tanah yang diperoleh dari analisis di laboratorium memenuhi salah satu kriteria jenis tanah Andisol yang memiliki sifat tanah andik.

Hasil penelitian Arabia et al. (2015a) tentang klasifikasi Andosol di University Farm Unsyiah Kabupaten Bener Bener Meriah, menunjukkan rata-rata bobot isi untuk seluruh daerah penelitian (P1, P2, dan P3) berkisar dari 0,82 sampai 1,80 $\mathrm{g} \mathrm{cm}^{-3}$. Pedon P2 dan P3 terdapat tiga horizon yang memiliki nilai bulk density $<0,90$. Pada $\mathrm{P} 2$ di horizon $\mathrm{Bw}_{2}(40-85$ $\mathrm{cm})$ memiliki nilai 0,82 $\mathrm{g} \mathrm{cm}^{-3}$. Pada $\mathrm{P} 3$ di horizon $\mathrm{Bw}_{1}(10-30 \mathrm{~cm})$ memiliki nilai 0,88, dan di horizon $\mathrm{Bw}_{2}(40-85 \mathrm{~cm})$ memiliki nilai $0,82 \mathrm{~g} \mathrm{~cm}^{-3}$. Hasil tersebut memenuhi salah satu syarat sifat tanah andik pada jenis tanah Andisol.

\section{C-Organik}

Kandungan C-organik tanah Andisol yang terdapat di lokasi penelitian berdasarkan Tabel 2 untuk setiap horizonnya tergolong dari sangat rendah sampai tinggi, semakin kebawah kandungan C-organiknya semakin menurun. Kandungan C-organik pada horizon Ap berkisar 4,44\%, horizon $\mathrm{AB}$ berkisar 3,95\%, horizon $\mathrm{Bw}$ berkisar 1,42\% dan horizon $\mathrm{BC}$ berkisar 0,98\%. Menurut Prasetyo (2005) kandungan C-organik tanah Andisol di Indonesia berkisar antara 6 sampai 15\%, namun demikian beberapa hasil penelitian menemukan kandungan C-organik tanah Andisol $<2 \%$. Tanah-tanah Andisol dengan kandungan bahan 
organik rendah kemungkinan telah mengalami proses degradasi. Berdasarkan penelitian Arabia et al. (2015a) juga memperlihatkan bahwa Andosol di University Farm Unsyiah Kabupaten Bener Bener Meriah memiliki kandungan C-organik di semua pedon dan horizon tergolong tinggi dan menurun sampai ke horizon bawah, yaitu berkisar dari 2,00 - 9,85\%.

\section{Basa-basa Tanah Dapat Ditukar}

Kation basa tanah dipengaruhi oleh faktor curah hujan dan sifat bahan induk. Tingginya curah hujan akan mengakibatkan kandungan basa-basa tanah semakin rendah akibat adanya proses pencucian yang semakin intensif (Arifin, 1994). Nilai basa-basa tanah dapat dipertukarkan di lokasi penelitian berdasarkan Tabel 2 adalah kation Ca-dd tergolong rendah berkisar dari 2,42 - 4,15 $\mathrm{cmol} \mathrm{kg}^{-1}, \mathrm{Mg}$-dd juga tergolong rendah yaitu berkisar dari 0,34 $0,36 \mathrm{cmol} \mathrm{kg}{ }^{-1}, \mathrm{~K}$-dd tergolong dari rendah sampai sedang berkisar dari $0,14-0,38 \mathrm{cmol} \mathrm{kg}^{-1}$, dan nilai Na-dd tergolong rendah yaitu berkisar dari $0,18-0,22 \mathrm{cmol} \mathrm{kg}^{-1}$.

\section{Kemasaman Dapat Ditukar}

Hasil pengukuran Al-dd pada Andisol di lokasi penelitian hanya diperoleh pada horizon Ap dan $\mathrm{AB}$, sedangkan di horizon $\mathrm{Bw}$ dan $\mathrm{BC}$ tidak terukur. Hasil Al-dd pada lapisan Ap adalah $0,80 \mathrm{cmol} \mathrm{kg}{ }^{-1}$ dan pada horizon $\mathrm{BC}$ adalah $0,48 \mathrm{cmol} \mathrm{kg}^{-1}$. Hasil $\mathrm{H}$-dd berkisar dari yang paling tinggi kemudian menurun seiring dengan dalamnya tanah, yaitu 1,00 - 0,24 cmol $\mathrm{kg}^{-1}$. Nilai kemasaman dapat ditukar Andisol dapat dilihat pada Tabel 2.

\section{Kapasitas Tukar Kation (KTK) Tanah}

Analisis KTK tanah Andisol di lokasi penelitian tergolong tinggi, berdasarkan Tabel 2 berkisar antara 25,20 sampai 31,60 $\mathrm{cmol} \mathrm{kg}^{-1}$. KTK tertinggi terdapat di lapisan olah tanah (Ap) pada kedalaman tanah $0-20 \mathrm{~cm}$. Apabila kandungan C-organiknya rendah maka hasil nilai KTK tanah yang akan diperoleh juga rendah. Hasil penelitian Arabia et al. (2015b) menyatakan bahwa hasil KTK tanah Andisol dengan subgrup Typic Hapludand di daerah Kabupaten Bener Meriah berkisar antara 20,05 sampai 26,40 $\mathrm{cmol} \mathrm{kg}^{-1}$ dan nilai KTK mengikuti pola kandungan C-organik di dalamnya. Kandungan $\mathrm{C}$-organik yang ditentukan di lapangan tergolong kriteria tinggi dan memiliki jumlah kation-kation basa yang lebih banyak sehingga nilai KTK nya lebih tinggi, sedangkan apabila kandungan $\mathrm{C}$-organiknya rendah maka memperoleh nilai KTK yang rendah.

\section{P-Retensi Andisol}

Pengukuran P-retensi Andisol hanya dilakukan pada horizon Ap $(0-20 \mathrm{~cm})$ dan horizon AB (20 - $38 \mathrm{~cm})$. Berdasarkan hasil analisis P-Retensi di laboratorium (Tabel 2) diketahui bahwa nilai yang diperoleh memenuhi syarat sifat tanah andik, dimana hasilnya $\geq$ 85\%. Nilai P-retensi pada horizon Ap yaitu 99,90\% dan pada horizon AB 99,80\%. Rendahnya nilai pada horizon $\mathrm{AB}$ di karenakan faktor kedalaman tanah, semakin kebawah maka nilainya akan semakin menurun.

\section{Kejenuhan Basa}

Berdasarkan Tabel 2, nilai KB jenis tanah Andisol yang diperoleh dari hasil analisis di laboratorium pada horizon Ap yaitu 12,15\% , horizon AB yaitu 10,61\%, horizon Bw yaitu $16,58 \%$ dan pada horizon BC yaitu 18,59\%. Dari hasil analisis tersebut menunjukkan tanah Andisol di BBH Gampong Aceh/Lembah Seulawah tergolong sangat rendah, dapat dikatakan 
kesuburan tanahnya relatif kurang subur. Akan tetapi jika dilihat dari penggunaan lahan di lokasi penelitian, untuk sekitaran penggalian profil tanah digunakan sebagai lahan budidaya masyarakat. Jika disesuaikan dengan kandungan C-organik tanah Andisol pada lapisan olah lebih tinggi dari pada horizon dibawahnya. Hal ini dapat saja terjadi akibat telah terjadinya proses degradasi lahan. Hasil penelitian Arabia et al. (2015a) menunjukkan bahwa Andosol di University Farm Unsyiah Kabupaten Bener Bener Meriah mempunyai kandungan kejenuhan basa yang tergolong rendah sampai sangat tinggi, yaitu berkisar dari 8,81 - 38,56\%.

\section{Fe dan Al Oksalat Andisol}

Persentase Alo tiap horizon berkisar dari 0,619 - 0,651\%, dan persentase nilai Feo tiap horizon berkisar dari 3,025 - 5,200\%. Hasil Kadar Alo + 1/2 Feo yang diperlukan untuk memenuhi salah satu syarat sifat tanah andik harus $\leq 2 \%$. Berdasarkan hasil perhitungan nilai yang diperoleh pada setiap horizonnya berkisar dari 3,35 - 5,51\% (Tabel 2). Hasil penelitian Ridwandi et al. (2013) menyatakan bahwa hasil Alo dan Feo pada jenis tanah Andisol di lereng utara Gunung Sinabung Kabupaten Karo memiliki sifat tanah andik, dikarenakan persentase Alo $+1 / 2$ Feo tiap horizon tanah memenuhi persyaratan yang memiliki persentase antara 0,96 - 12,76\%. Menurut Gusbiandha (2011) debu volkanik yang kaya dengan mineral liat amorf atau alofan mengandung banyak Al dan Fe. Logam-logam ini akan dibebaskan seiring dengan perubahan iklim. Khelasi antara asam humik dan Al dan Fe tersebut, membentuk khelat logam-humik, yang juga akan meningkatkan retensi humus terhadap dekomposisi mikrobiologis.

\section{Klasifikasi Tanah}

Sistem klasifikasi tanah yang digunakan dalam penelitian ini adalah berdasarkan Soil Taxonomy (Soil Survey Staff, 2014). Klasifikasi tanah Andisol dapat dilihat pada Tabel 3.

Tabel 3. Klasifikasi tanah Andisol dapat dilihat pada Tabel 3.

\begin{tabular}{cccccccl}
\hline $\begin{array}{c}\text { Susunan } \\
\text { Horizon }\end{array}$ & Epipedon & $\begin{array}{c}\text { Horizon } \\
\text { Penciri }\end{array}$ & RK & KBB & KM & KRS & \multicolumn{1}{c}{$\begin{array}{c}\text { Nama tanah } \\
\text { (ordo-famili) }\end{array}$} \\
\hline Ap & - & - & Udik & Medial & Campuran & Isohipertermik & Ordo: Andisol; \\
AB & Umbrik & - & & & & & Subordo: Udand; \\
Bw & - & Kambik & & & & & $\begin{array}{l}\text { Great group: Hydrudand; } \\
\text { Subgrup: Eutric Hydrudand }\end{array}$ \\
BC & - & - & & & & & $\begin{array}{l}\text { Famili: Eutric Hydrudand, } \\
\text { medial, amorfik, } \\
\text { isohipertermik }\end{array}$ \\
\hline
\end{tabular}

Sumber: Hasil Survey Lapangan (2018)

Keterangan: Susunan Horizon; Horizon Penciri; RK (Rejim Kelembaban); KBB (Kelas Besar Butir); KM (Kelas Mineralogi); KRS (Kelas Rejim Suhu).

Andisol di BBH Gampong Aceh/Lembah Seulawah berdasarkan Tabel 3 dicirikan memiliki horizon penciri atas umbrik, dengan tebal lapisan tanah horizon $\mathrm{AB} \geq 18 \mathrm{~cm}$ yaitu $18 \mathrm{~cm}$, mempunyai kandungan $\mathrm{C}$-organik $\geq 0,6 \%$ yaitu $1,53 \%$, dan mengandung kejenuhan basa $<50 \%$ yaitu $10,62 \%$. Horizon penciri bawah dicirikan kambik karena tekstur fraksi pasir di horizon Bw tergolong sangat halus atau lebih halus (lempung berdebu), atau struktur tanah telah terbentuk yaitu gumpal bersudut, dan warna tanah sebenarnya tergolong lebih merah dari horizon di atasnya atau di bawahnya tetapi hasil pengamatan di lapangan menunjukkan antara horizon di atas dan di bawahnya memiliki warna tanah yang sama yaitu 7,5YR 3/4. 
Kategori ordo tanah termasuk Andisol karena mempunyai lapisan dengan sifat andik $\geq$ $60 \%$ pada kedalaman $<60 \mathrm{~cm}$. Sifat tanah andik ditemukan pada lapisan Bw dengan kedalaman tanah $30-60 \mathrm{~cm}$. Kandungan C-organik <25\% yaitu 1,42\%, bobot isi tanah < $0,90 \mathrm{~g} \mathrm{~cm}^{-3}$ yaitu $0,73 \mathrm{~g} \mathrm{~cm}^{-3}$, nilai P-retensi tanah $\geq 85 \%$ yaitu $99,90 \%$, dan kadar Alo $+1 / 2$ Feo $\geq 2 \%$ yaitu 5,51\%. Kategori tingkat subordo tergolong Andisol yang memiliki rejim kelembaban tanah udik maka termasuk Udand. Tingkat great group tergolong Udand yang mempunyai sifat tanah andik pada satu lapisan atau lebih dengan ketebalan total $35 \mathrm{~cm}$ di antara permukaan tanah mineral atau batas atas lapisan tanah organik, mana saja yang lebih dangkal maka termasuk Hydrudand. Kategori subgrup tergolong Hydrudand yang mempunyai satu horizon atau lebih dengan ketebalan total $15 \mathrm{~cm}$ atau lebih yang keseluruhannya mengandung jumlah basa-basa terekstrak lebih dari $25,0 \mathrm{cmol} \mathrm{kg}$ dalam fraksi tanah halus, di antara kedalaman $25 \mathrm{~cm}$ dan $75 \mathrm{~cm}$ diukur dari permukaan tanah mineral atau dari batas atas lapisan organik dijumpainya sifat-sifat tanah andik, mana saja yang lebih dangkal maka termasuk Eutric Hydrudand.

Kategori tingkat famili adalah Eutric Hydrudand, kelas besar butir medial yang meliputi tanah dengan sifat tanah andik dengan fraksi tanah halus dan mempunyai fragmen batuan < $35 \%$. Kelas mineralogi di lapangan digolongkan amorfik, karena umumnya pada Andisol didominasi oleh mineral amorf (alofan, imogilit, ferihidrit atau kompleks Al-humus), sedangkan hasil dari laboratorium memperlihatkan kelas mineralogi campuran (bayerit dengan nilai peak $3.20 \AA$, kaolinit dengan nilai peak $3.54 \AA$, dan feldspar dengan nilai peak $4.04 \AA ̊$ A). Hal ini dapat terjadi disebabkan oleh metode analisis sinar-x yang digunakan berbeda. Jenis mineral dari Andisol dapat dilihat pada Gambar 1.

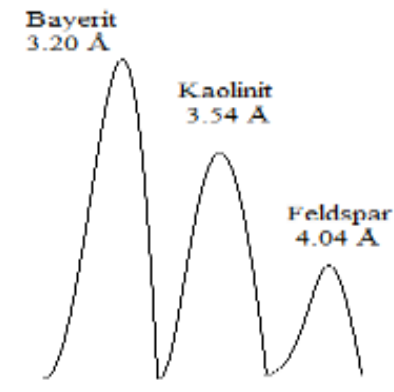

Sumber: Hasil Anlisis XRD Laboratorium FMIPA Fisika Material Universitas Syiah Kuala (2018)

Gambar 1. Kurva difraktogram sinar-x Andisol

Kelas rejim suhu tanah digolongkan isohipertermik. Kategori famili Andisol adalah Eutric Hydrudand, medial, campuran, isohipertermik (Tabel 3). Menurut Arabia et al. (2012), terbentuknya mineral liat seperti kaolinit lebih banyak dari pada mineral lainnya di dalam tanah dipengaruhi oleh besarnya curah hujan.

\section{SIMPULAN DAN SARAN}

Andisol di BBH Gampong Aceh Besar/Lembah Seulawah dicirikan memiliki sifat morfologi sebagai berikut: (a) struktur tanah remah; konsistensi tanah basah agak lekat; terasa licin (smeary); (b) sifat tanah andik pada horizon Bw: C-organik <25\% (1,42\%); bobot isi 
tanah $<0,90 \mathrm{~g} \mathrm{~cm}^{-3}\left(0,73 \mathrm{~g} \mathrm{~cm}^{-3}\right) ;$ P-retensi $\geq 85 \%$ (99,90\%); dan kadar Alo $+1 / 2 \mathrm{Feo} \geq 2 \%$ (5,51\%); (c) epipedon umbrik: tebal horizon $\mathrm{AB} \geq 18 \mathrm{~cm}(18 \mathrm{~cm})$; value lembab < 3 (3); Corganik $\geq 0,6 \%(3,95 \%)$; dan KB pH7 < 50\% (10,62\%); (d) horizon penciri bawah kambik: tekstur pasir sangat halus atau lebih halus (lempung berdebu); atau warna tanah lebih merah dari horizon diatasnya atau dibawahnya (sama-sama 7,5YR 3/4); atau struktur telah terbentuk (gumpal bersudut); dan diklasifikasikan kedalam ordo Andisol, subordo Udand, great group Hydrudand, subgrup Eutric Hydrudand, dan tingkat famili Eutric Hydrudand, medial, campuran, isohipertermik.

Saran dari penelitian ini adalah perlu dilakukannya penelitian lanjutan untuk mengupayakan usaha konservasi yang cocok untuk diterapkan di lokasi penelitian tersebut, serta menemukan pemupukan yang benar-benar tepat untuk pengembangan produksi tanaman di lokasi tersebut.

\section{DAFTAR PUSTAKA}

Adiwiganda, R. 1998. Pedoman Klasifikasi Kesuburan Tanah di Areal Perkenbunan Kelapa Sawit. Warta PPKS, Medan. Vol 6(2): 63-69.

Arabia, T., A. Karim, dan Manfarizah. 2012. Klasifikasi dan Pengelolaan Tanah. Universitas Syiah Kuala. Darussalam, Banda Aceh.

, Zainabun, A. Karim, dan I.P. Sari. 2015a. Klasifikasi Andosol Berdasarkan Sistem Soil Taxonomy di University Farm Unsyiah Kabupaten Bener Meriah. Jurnal. Agrosamudra. Vol 2(1): 11-20.

A. Karim, Zainabun dan I.P. Sari. 2015b. Karakteristik tanah Typic Hapludand di University Farm Kabupaten Bener Meriah. Jurnal. Agrosamudra. Vol 2(2): 94- 95.

Darmawijaya, M.I. 1990. Klasifikasi Tanah: Dasar-dasar Teori bagi Penelitian Tanah dan Pelaksanaan Pertanian di Indonesia. Cetakan kedua. UGM Press, Yogyakarta.

Fiantis, D. 2012. Morfologi dan Klasifikasi Tanah. Universitas Andalas, Padang.

Gusbiandha, A.A. 2011. Morfologi dan Karakteristik Kimia Tanah Andisol pada Penggunaan Lahan di Desa Kuta Rakyat Kecamatan Namanteran Kabupaten Karo. Universitas Sumatera Utara, Medan.

Handayanto, E. 1987. Dasar-Dasar Klasifikasi Tanah. Jurusan Tanah Fakultas Pertanian Universitas Brawijaya, Malang.

Pusat Penelitian dan Pengembangan Geologi. 1981. Peta Geologi Lembar Banda Aceh (Sumatra Geologi Map of the Banda Aceh Quadrangle, Sumatra). Bandung, Indonesia.

Purnomo. 2003. Morfologi dan Beberapa Sifat Fisik Tanah di Bawah Vegetasi Karet dan Vegetasi Campuran di Sekitar Areal Perkebunan PTPN VII Unit Usaha Way Galih. Skripsi. Universitas Lampung. 75 hlm. 
Ridwandi, Mukhlis, dan M. Sembiring. 2013. Morfologi dan klasifikasi tanah lereng utara Gunung Sinabung, Kabupaten Karo Sumatera Utara. Jurnal. Agroekoteknologi.2(1):324-332

Soil Survey Staff. 1990. Keys to Soil Taxonomy. $4^{\text {th }}$ ed. AID. USDA. SMSS. Technical Monograph No. 19. Blacksburg, Virginia. 280 p.

372 hal. 2014. Keys to Soil Taxonomy. Twelfth Edition. Washington. USDA. 